Chapman University

Chapman University Digital Commons

Peace Studies Faculty Articles and Research

Peace Studies

3-31-2016

De Facto Sovereignty and Population Displacement as Tools of Conflict

Hilmi Ulas

Follow this and additional works at: https://digitalcommons.chapman.edu/peace_articles

Part of the International Relations Commons, Other Political Science Commons, and the Peace and Conflict Studies Commons 


\section{De Facto Sovereignty and Population Displacement as Tools of Conflict}

\section{Comments}

This article was originally published in Politikon: The IAPSS Journal of Political Science, volume 29, in 2016. https://doi.org/10.22151/politikon.29.17

Creative Commons License (c) () (9)

This work is licensed under a Creative Commons Attribution-Noncommercial 4.0 License 


\title{
De Facto Sovereignty and Population Displacement as Tools of Conflict
}

\section{Hilmi Ulas}

Hilmi Ulas, 27, from Nicosia (Cyprus), is a PhD Candidate at the School for Conflict Analysis and Resolution, George Mason University in Virginia, USA, where he previously obtained his MS in Conflict Analysis and Resolution. He obtained his BA in Political Science in Grinnell College, Iowa, US A where his thesis entitled "The Devil's Triangle in the Mediterranean?" evaluated the possibility of a peace agreement in the Cypriot Conflict. He currently works at George Mason University - where he has taught for the last two years - as a Graduate Research Assistant. His interests are in peacebuilding, conflict resolution, comparative politics, international law and policymaking, and international security studies. His dissertation work focuses on evaluating the impact of unrecognition of a state on the conflict and conflict resolution processes where the said state is involved.

\begin{abstract}
Two largely debated questions in the realm of international relations are the roles of post-Cold War Russia and China within the current global context. However, the debates in the literature fails to take into account the fact that both superpowers employ the same tactic: the asymmetrical conquest of new territory as promoted by historical claims, retroactively justified through population displacement. Subsequently, debates on the topic mistakenly focus on elite motivations rather than what can be controlled: the responses of the international community to the abovementioned tactics. I will document why mainly Russia but also China have opted to use the tactic of territorial conquest and demonstrate how the international community has tacitly promoted the use of this tactic. I will ultimately argue that there is a need to create international standards for sovereignty and that a move from inactive conflict avoidance to active conflict resolution is necessary.
\end{abstract}




\section{Introduction: A Recurrence of the Cold War?}

George Santayana, a Spanish philosopher of the modern era, quite efficiently captured a truth of our world, "Those who cannot remember the past are condemned to repeat it." Therefore, as the field of international relations considers the emerging threats to global security and order, it must also consider threats from recent history and attempt to prevent their recurrence. In contemporary history, the state of Cold War between the Western Block - spearheaded by the USA - and the Eastern Block - spearheaded in turn by Union of Soviet Socialist Republics (USSR) - which lasted from 1947 until 1991, was clearly the time when threats to security were most sharply felt throughout the world. In fact, the possibility of nuclear annihilation appeared more probable than not, and theories abound on mutually assured destruction (M.A.D.) and how it would hopefully serve as a deterrent for all rational elites from directly and militarily engaging in and 'heating up' the war.

Nevertheless, Cold War kids grew up feeling 'the Red Terror' or the 'Imperialist Pigs' breathing down their necks and that nuclear bombs were about to rain down from the sky, are still scarred with the traumas of this period. Even cities bear witness to the extent of the perceived threats of the Cold War, and many major cities around to world still host nuclear bomb shelters. Considering the facts that many proxy wars were waged during this period thus claiming many lives, and that arms and nuclear proliferation naturally occurred, one can confidently conclude that avoiding a resurgence of Cold War rivalries and conflicts is one of the prime directives of our generation of scholars and practitioners.

As the Cold War ended in 1991 with the USSR's collapse, many scholars- such as Francis Fukuyama - thought that an era of perpetual peace might descend, while many others - such as Samuel Huntington - thought that, at the very least, ideological wars were over and, while conflicts would still occur, they would be along other modes of difference. In this atmosphere, the relations between the former Eastern and Western blocs improved, while the world moved towards a unipolar rather than a bipolar arrangement of powers, where the USA ruled supreme.

Nevertheless, China's meteoric rise vis-à-vis its economic prowess and its rapidly increasing population pushed it to the status of a Great Power. China projected this power by seeking to expand its territory, incorporating Tibet and actively engaging in disputes over islands and territories in the South China Sea. Indeed, these disputes have put China at odds with South Korea, Japan, and Vietnam, among others ${ }^{274}$. In the meantime, Russia felt ignored and trampled by the West and decided that it was time for Russia to re-assert - at the very least - its regional power and thus 'helped liberate' former USSR protectorates such as Abkhazia and South Ossetia (from Georgia), Nagorno-Karabakh (from Azerbaijan), Transnistira (from Moldova), and lastly Crimea (from Ukraine $)^{275}$. Especially in regards to its actions in partitioning Crimea from Ukraine, Russia risked re-igniting the long-smoldering flames of the Cold War era, pitting itself directly against the former Western-Bloc and the European Union (EU). If this was not enough, both Russia and China have at least abetted and have at most directly carried out ethnic cleansing; i.e. population

\footnotetext{
274 See http://www.foxnews.com/world/2015/07/21/chinese-not-backing-down-over-south-china-sea-dispute/ [retrieved 08/31/2015].

275 See http://www.nytimes.com/2004/03/14/world/cia-says-russia-could-try-to-reassert-itself-after-a-putinvictory.html [retrieved 08/31/2015].
} 
displacement, and population replacement, in order to further justify their actions and bring their newly acquired territories under their own jurisdiction and authority.

Both the actions of China and Russia constitute security threats at regional and global levels, especially as they could lead to open warfare with economic and socio-political repercussions, including loss of life and creation of refugees and IDPs, that would be both undesirable and unimaginable. Therefore, we must necessarily wonder how we can prevent further similar actions from both China and Russia as well as any other international actors, while also attempting to deescalate this situation. For the purposes of understanding and intervening into the phenomenon of Sino-Russian forceful land acquisition and said territories' de facto incorporation through conquest and ethnic cleansing, many have sought to understand the motivations underlying said actions, as I will demonstrate in the following literature review. However, I have decided to deviate from this route and problematize the international context within which forceful land acquisition and population displacement can be executed without repercussions. Through my study, I will argue that the international community has been unable to assert a universally acceptable definition of sovereignty, which undermines the practice of this concept. Moreover, the international community has also failed to come up with a constructive strategy for addressing de facto states or forceful acquisition of land, instead following a freezing and forgetting strategy, which is ineffective at its best and destructive at its worst. Therefore, after underlining the shortcomings of this strategy and its role in the current Sino-Russian trends towards aggression, I will conclude this paper by discussing potential alternatives.

\section{Literature Review: Understanding Elite Motivations?}

For the purposes of this paper, I have reviewed works which have focused on analyzing the respective roles of Russia and China in the post-Cold War world. For reasons outlined in the introduction section of this paper, it should come as no surprise that the role and actions of both of these parties are of great concern to scholars and practitioners alike. Will the ex-foes of the Western Bloc re-emerge, threatening war and causing instability, especially with the Eurozone now much weaker and with the USA having burn out from wars in the Middle East? Or can these two rising powers be integrated with the West in an amiable, constructive fashion, thus ushering international cooperation? As the needles have staggeringly turned to point towards the former possibility being realized, many have attempted to understand the Russian and Chinese elites' rationale, while others have attempted to explain the behavior of Russia and China through historical and international contexts. While this paper will dispute such approaches and subsequently claim that they are unsuitable for the purposes of conflict prevention, management, and resolution, I believe that understanding the current lines of thinking will be essential to situate my arguments within the field.

Russia and China have risked war with the former Western Bloc and their allies, as well as tarnishing their reputation around the world especially vis-à-vis human rights, in order to accomplish their respective land gains. Indeed, Russia angered the West when it engaged in wars with Georgia - which has been getting close with the NATO for a long time - and then with Ukraine - which was being scouted by the EU. In the meantime, China - which forcefully incorporated Tibet into the People's Republic in the mid-20 $0^{\text {th }}$ century - utilized similar tactics in order to de facto end several maritime debates over the ownership of islands as well as the 'borders' 
of its maritime sovereignty. In fact, China has gone as far as constructing artificial islands to solidify its maritime claims. Ever since 2009 where UNCLOS (United Nations Convention on the Law of the Sea) forced nations to claim ownership of maritime zones in order to extract hydrocarbons from the South China Sea, China engaged actively in conflicts with Vietnam, Philippines, and Malaysia, while also threatening war with Japan and South Korea. This not only strained Chinese relations with neighbors and the USA, but also damaged China's reputation - which has been especially hurtful as China attempts to rise as a Global Power ${ }^{276}$.

Given that land gains are small and the risks as well as the damage consequently suffered are quite considerable, one necessarily must wonder why Russia and China have taken a more aggressively assertive approach in their international relations and foreign policy of late. This is especially true as the risks of war and lack of access to energy resources pose significant security threats to not only Russia and China's respective regions but also for the globe as a whole.

Russia and China have received a lot of backlash due to their actions: the former was hit with a multitude of sanctions from the West due to its actions in partitioning Crimea from Ukraine, whereas the latter caused threat perception in the staunch US ally, Japan, to rise and thus USA has become more engaged in this region, undermining Chinese interests. Many complicated answers have been sought, complicated due to the fact that these answers simply speculate on the value of unknowable quantities. Indeed, these attempts at explaining Russian and Chinese behavior perceived to be irrational given their costs as compared to their gains - alternatively harken to the two parties' glorified histories and attempts at re-capturing them; identify a need to alleviate domestic pressures and scrutiny due to a decline in the economy; identify a surge in nationalism to allow for autocratic leadership; or point at ethnic kinships. Yet many others assume a lack of trust and persistent enmity between the West and these two Great Powers as based in history; indeed, Russia and China had stood together as staunch allies against the Western Bloc for many years. This theory of Great Power Games sometimes also includes modern tensions over Kosovo, Libya, and Iran, as well as Sudan ${ }^{277}$. Within this tradition, Russian and Chinese actions serve to perpetrate proxy wars in order to undermine other powers in their respective regions and, in turn, gain influence themselves.

While all of the factors identified above are important and probably contribute, one way or another, to the current conflicts perpetrated by the Sino-Russian allies of old, it is indeed hard to determine the policymaking elites' underlying motivations. Russian elites have claimed ethnic kinship with and a 'responsibility to protect' the ethnic Russians of Georgia and Ukraine. The Chinese have harkened to old historical claims, producing ancient texts and maps in order to demonstrate their claims to the maritime zones in South China Sea to be justified. However, the West does not seem to recognize these claims as valid and in fact approaches them with bags rather than pinches of salt. Nevertheless, sometimes, parsimony rules and the most direct, concise, and clear answer is the best answer.

\footnotetext{
276 See http://www.theguardian.com/commentisfree/2015/aug/29/china-may-fear-reputation-damage-more-thanmilitary-threats-over-south-china-sea .

277 See http://foreignpolicyblogs.com/2015/07/09/russia-west-tensions-play-out-over-srebrenica/ [retrieved 08/31/2015] and http://www.cfr.org/councilofcouncils/global memos/p36607 [retrieved 08/31/2015], as well as http://venturesafrica.com/china-catches-the-wests-sickness-in-south-sudan/ [retrieved 08/31/2015].
} 


\section{Occam's Razor: Action as a Result of Capability and Lack of Standards}

In the preceding section, this paper underlined the fact that the foreign policy, international relations, and security studies literature available have all approached the question of understanding the Russian and Chinese actions since the latter part of the 2000s in an unintuitive fashion. Indeed, attempting to understand elite motivations can only be based on dubious assumptions or the suspect words of the said elites. In addition, claims that historical rivalries or attempts to capture past greatness must necessarily influence elite behavior would also prove hard to verify. Subsequently, this paper - following in the footsteps of Coleman and Lederach - attempts to provide a parsimonious explanation that can account for the baffling and aggressively assertive behaviors of Russia and China.

So, the question is: what is the simplest answer to the question of why Russia and China have sought to assert their territorial claims through the forceful acquisition of lands despite the associated risks? Because they can and that they can afford to; in addition, the international community is 'weaponless' in the face of this type of tactic. There are three parts of reasoning for this claim, which I will elaborate on.

Firstly, both Russia and China have targeted much weaker adversaries against whom they could justify their actions - be it ethnically in the case of the former or historically in the case of the latter. Therefore, the military might of either Russia or China alone was enough to dwarf the power of their chosen adversaries. Not only this, but the general positions of Russia and China vis-à-vis the global balance of power were also much greater than their opponents', therefore it was and remains unlikely that - in most of these cases - the international community will choose to actively side against them. Here, Crimea has served as an exception due to its proximity with the EU. However, neither when Russia helped partition Abkhazia and South Ossetia from Georgia, nor when China decided to aggressively assert its hold over the South China Sea despite claims by Vietnam, Philippines, and Malaysia - among others - did the international community act against these two powers. In fact, at the most, the international community issued condemnations through the United Nations - which, as research has proven time and again, is quite an ineffective countermeasure. Nevertheless, as power discrepancies are natural and will therefore persist within the international system for the foreseeable future, there is not much the international community can do to prevent the gains made by the Great Powers at the expense of weaker countries. Therefore, we need to understand the other enablers of Russian and Chinese actions in order to prevent their recurrence.

Secondly, the international community facilitates the forceful acquisition of lands as it does not have either an appropriate response or an effective deterrence mechanism to prevent the utilization of this tactic. At best, the international community imposes sanctions on the 'perpetrators', which only works on those countries that can be alienated and cannot afford isolation from the international community. However, when it comes to both Russia and China, they can weather the storm due to the availability of natural resources and their general economic might. Furthermore, not all countries can afford to cut their relations with either Russia or China, which assures their global economic activity will still continue even if at a comparatively reduced level. For example, both Russia and China have depended on each other in order to break away from 
the international isolation that they have perceived and distance themselves from the image of 'isolated castles' with which they have been branded.

In addition, while sanctions aim to cause internal strife between the citizens and the governments of the targeted countries, this seems to backfire more often than not. Indeed, as long as the targeted governments have acceptable excuses for their actions which begot the sanctions in the first place, they seem to succeed in framing the international community as unjust aggressors. Therefore, not only do the citizens feel persecuted by the international community - and, in fact, the perception of USA has hit an all-time low in Russia, even lower than during the Cold War ${ }^{278}$ - but they also support their own government against the external aggressors regardless of whether the said government is democratic or authoritarian. Subsequently, the Russian and Chinese approval ratings rise after their aggressive and assertive actions, leading them to be capable of repeatedly using similar tactics. Clearly, then, sanctions do not provide for a viable method in dealing with land acquisitions through conquests. On this note, it appears that preventing the justification of such land acquisitions within the international realm through standardized laws might be the best tactic.

The third factor - and possibly the most important one - here is: how valid are forceful land acquisitions as conducted through conquest/military might? According to the Stimson Doctrine ${ }^{279}$, which is a large part of modern international law, the international community calls for the nonrecognition of governments established through the use of force. This doctrine was adopted as the Montevideo Convention's Article 11, which is the most widely accepted document for establishing sovereignty. However, herein lies the problem within the international system: Even legal scholars have yet to come to a consensus on when and why states should be recognized and how and why can an entity be sovereign over certain territories and under what conditions this sovereignty can be breached ${ }^{280}$. Moreover, these laws appear to be interpreted to suit the politics of the international community ${ }^{281}$. This politicization of law then allows for subjective judgements, which then allow for the calls of foul play - a deadly mixture.

Indeed, the non-Western Bloc countries have always perceived a biased implementation of the rules regarding sovereignty and the international acceptance or rejection of de facto forceful land acquisitions. For example, the international community has adopted the Responsibility to Protect (R2P) as a guideline for when interveners can eschew the sovereignty of a State for the purposes of conducting an intervention ${ }^{282}$. Since its adoption, R2P has been invoked twice - once in Kosovo and once again in Libya. In both cases, it was the former Western Bloc countries which spearheaded the interventions and, in the former case, the intervention involved the bombing of Belgrade, which appeared to many to be a case of using excessive force. Moreover, much like with the Russian interventions into Abkhazia and South Osetia, the Kosovan intervention led to the de

278 See Gozman, L. (n.d.). Why Russians Liked Americans Better During the Cold War; http://www.politico.com/magazine/story/2015/04/russians-cold-war-116736 [retrieved 08/30/2015].

279 This doctrine, much like the prevalent distinction between sovereign and puppet states, was widely adopted as a response to the Japanese invasion of Manchuria in China and their subsequent building of a dependent, 'marionette' state in this territory in 1931.

${ }^{280}$ See Grant's The Recognition of States.

281 See Caspersen, 2011. See also Mulaj, p. 54. Lastly, see Closson 2011 (with emphasis).

282 According to R2P, this is allowed when the State is the perpetrator of or otherwise complicit to human rights abuses, war crimes, and crimes against humanity - such as ethnic cleansing, genocide, etc. 
facto partition of Kosovo from the former Serbia-Montenegro and current Serbia, which claimed the territories of Kosovo. In fact, many Serbs still feel that Kosovo is an integral part of and therefore should belong to Serbia. Despite such feelings, the international community has allowed for the independence of Kosovo. However, the claims of R2P were not validated for the Russian interventions in Abkhazia and South Osetia, whose sovereignty and independence has since been in dispute. Of course, these cases were not necessarily evaluated on a political basis; however, in the absence of internationally-accepted standards regarding forceful land acquisitions and de facto statehood, claiming discrimination is radically facilitated.

This takes us to the fourth point: Russia and China can get away with their actions as there are no internationally-accepted or internationally-executed standards for sovereignty. This is quite natural, for the phenomenon of what we will call De Facto States, Unrecognized States, Quasi States, or Puppet States or otherwise Conquered Territories is a recent one. Indeed, there is general agreement that these entities are a by-product of the evolving international system and the consequent conceptualization of sovereignty as an inviolable right of any State and as being affixed in territorial integrity.

\section{Conquests in the Modern Era: A Recipe for Disasters}

Contrarily, one of the main principles of modern international law is that of self-determination of minorities, which was revitalized at the end of World War I in response to the growing power of nationalism and the necessary downfall of empires. The principle of self-determination, which states that nations can rightfully pursue autonomy in the international realm yet fails to define what is to constitute a nation or what form autonomy should take, was adopted into the UN Charter in the 1940s and subsequently drove minorities to wage wars of independence in a world that disallowed territorial breakaways from States except in very exceptional circumstances. Subsequently, many of these movements for independence that survived military campaigns by States to quash them claimed the latter's territories and formed their own governments, only to be 'disowned' by the international community. Thus, these contested states continued to exist in a limbo sometimes for decades, until they were (more commonly) forcefully or (less commonly) peacefully reintegrated into their parent states ${ }^{283}$, or until they won their independence. In fact, most of these contested states continue to exist around the world today, and experts expect that there might be many more of these entities in the making ${ }^{284}$. Likewise, contested territories which have been folded into the control of an existing state also can exist perpetually without a military defeat of the conquering state by another. There are two reasons for Russia and China's capability of forceful land acquisition: ambiguities regarding de facto entities, as well as the ineffectiveness of the freezing and forgetting approach aimed at dealing with them, the latter of which I will elaborate on shortly.

\section{De Facto Statehood and the Freezing and Forgetting Tactic}

According to Pegg, these de facto entities fulfill most or all of the criteria as set forth by the Montevideo Convention on the Rights and Duties of States; a treaty signed on December 26 ${ }^{\text {th }}, 1933$. Subsequently, when territories are obtained in a de facto fashion, their existence can be perpetuated qua de jure

\footnotetext{
$283 \mathrm{~A}$ parent state is a reference to the state on whose territories a contested state is established and with whom the aspiring state contests its sovereignty.

${ }^{284}$ According to Ker Lindsay (2012), there are potentially 38 contested states lying dormant in Europe alone. He claims that, based on how the international community deals with existent cases, none or all could make attempts at independence. These might potentially include novel entities in Scotland and the Basque region of Spain.
} 
acceptance. According to this treaty's first article, diplomatic recognition of statehood within the context of customary international law requires: a) a permanent population; b) a defined territory; c) a functioning government ${ }^{285}$; and ultimately d) the capacity to enter into relations with other States. This definition serves the declaratory theory of statehood, which claims that a state can exist in absentia of recognition from other states; that is, a state exists as long as it fulfills the abovementioned criteria and has declared independence ${ }^{286}$. Likewise, territories 'liberated' in a de facto fashion can be ruled over by their liberator, such as in the case of China. On the basis of and through the use of the Montevideo criteria for and conceptualizations of statehood, Pegg demonstrates that the unrecognized entities in the international realm [such as Somaliland, Eritrea (pre-independence), North Cyprus, and Tamil Eelam (pre-destruction)] fit the criteria for statehood and thus must be dealt with accordingly. Therefore, according to Pegg, the unrecognized entities of the international realm should be defined as states without recognition that have been built in a recognized state's territories through the use of violent methods ${ }^{287}$ and through unilateral measures. Given this, it becomes easy to see how partitioned states can survive and establish a legitimate existence as the requirements appear minimal. Subsequently, Russia and China have both been able to establish legitimacy for these new territories which function. Duly, the Montevideo Convention and subsequently Pegg's definition of De Facto Statehood, which is based on the former, are problematic.

First and foremost, the Montevideo Convention has come under criticism from many sovereign states, as they regard the criteria for statehood as set forth in the convention to be insufficient and too loose. The reason for this perception is that many unrecognized entities in the world, such as Taiwan (Republic of China) - and, as Pegg demonstrated, Somaliland, Eritrea, North Cyprus, and Tamil Eelam, - could claim statehood under the Convention. Given this, it is not surprising that Pegg assumes constancy as to the fulfillment of the Montevideo Convention and thus the attainment of statehood by unrecognized entities. However, even Pegg acknowledges that some unrecognized entities' territories change over time (e.g. unrecognized Eritrea and Somaliland, whose control of territory varies greatly; Tamil Eeelam gained and lost much territory as well before it was ultimately destroyed by the Sri Lankan government forces) despite his argument of statehood. In fact, the support for the governments of unrecognized entities also wavers, as observed in Abkhazia in 2014, the TRNC in 2002-2004 and again in 2015, and in South Sudan another fact missed in the assertion of de facto statehood. Ultimately, then, the Montevideo Convention-based definition of unrecognized entities as De Facto States asserts statehood in a loose yet static manner that fails to capture the dynamic nature of unrecognized entities.

Secondly, due to Pegg's dependence on the Montevideo Convention for his proposed definition, he also necessarily buys into the declaratory theory of recognition, which was described above. In fact, this interpretation of diplomatic recognition (i.e. the declaratory theory) was the one used in the case of Kosovo. However, using this definition ignores the fact that constitutive theory, which calls

\footnotetext{
285 Although which type of government is necessary (e.g. authoritarian or democratic; republic or kingdom) or the criteria and/or methods regarding how the international community is to decide which governments are functioning and which are not, are not well-defined.

${ }^{286}$ This was set out in Article 3 of the Montevideo Convention.

${ }^{287}$ Pegg rightfully makes a distinction between peaceful secession (e.g. through the use of renerandi) as compared to armed secession.
} 
for the recognition of an entity as a state by other peer States of the international community if it is to be treated as such in the eyes of international law, suggests another criteria (i.e. level of recognition) which goes ignored within Pegg's definition.

Clearly, there are no undisputed international standards for the establishment and absorption of independent territories, which allows for the creation of favorable de facto situations as a tool for the powerful nations to pursue their interests in any conflict. In fact, Indonesia utilized this lack of clarity in subsuming the territory which now belongs to East Timor. Given Indonesia's alliance with the global powerhouse USA and the regional powerhouse Australia, in addition to its relative power in the international realm, they got away with doing so for decades. The change in this relationship only came when Indonesia broke ties with its powerful allies, thus displacing their favor towards East Timor's independence ${ }^{288}$. Moreover, as sovereignty is assigned through certain criteria with objective definitions yet subjective fulfillers, any state can claim that another has lost the right to sovereignty over given territories due to a perceived lack of capacity to protect their citizens' lives or provide for their basic human rights. In fact, Russia claimed that the Ukrainian Government was threatening the lives and rights of ethnic Russians in the Crimean Region, thus losing its right to be sovereign over Crimea and prompting Russia to invoke R2P to firstly partition and then absorb this territory. Given this, it should come as no wonder that Russia and China are capable of employing this tactic.

Last but not least, the ineffectiveness of freezing and forgetting as an international policy for dealing with de facto acquisitions should be problematized. In the case of China, this tactic turns into 'feigning ignorance' as the Chinese actions have yet to lead to full-blown warfare and thus have yet to require freezing. In this tactic, the international community helps mediate a ceasefire and enforces it through peacekeeping or close monitoring of the conflicting parties. Through this, the manifest violent conflict process is dealt with; however, the structural, communal, psychological, cultural, etc. issues which led to the conflict in the first place are left to fester. Nevertheless, as the most harmful phase of the conflict has been frozen by this time, the international community forgets such conflicts until such time as either the conflicting parties resume with large-scale violence or the de facto territories are reintegrated to its parent willingly - or, for that matter, unwillingly. Freezing and forgetting is sustained through peacekeeping due to a lack of violence, which removes the immediacy for addressing these conflicts.

Moreover, due to the level of isolation-driven dependency ${ }^{289}$ UBSs have on their sponsors (more on this shortly), the strength of the de facto territories' governments, which tend to outsource their administrative duties (and hence their autonomy and independence) to the more powerful sponsor state $^{290}$ and gain financial support in return, become quite strong to the point that their survival is guaranteed - all the while reducing their levels of democracy, as they do not depend on their citizens' support for maintaining their power ${ }^{291}$. Additionally, the fact that the sponsor state's support can virtually guarantee their continued existence causes UBSs to lose interest in international acceptance, which demotivates them from accomplishing democratizing reforms;

288 See Cotton's Against the Grain, Martin's Self-Determination in East Timor, and Bacharuddin's The Right for SelfDetermination.

289 Closson, pp. 67-68; Mulaj, p.47.

290 Harvey and Stansfield, p. 19.

291 Ibid., p. 23. 
this effect is further exacerbated as the elites of said territories surely realize that their citizens have no real alternatives ${ }^{292}$. Clearly, the international response to the creation of de facto states directly plays into the hands of the aggressor states, allowing for their hold in the newly acquired territories to solidify.

Of course, this process of solidifying 'sponsor state' authority on de facto states is aided by the actions of the aggressor states. Given that the international community willingly isolates the domestic happenings in these de facto states and thus also isolating them from international law, the sponsor states are unchained to use any means necessary to rule over these territories. For this purpose, there is only one effective tactic: ethnic cleansing. Indeed, through ethnic cleansing, a state can make sure that only the populations that identify with them, and would therefore be loyal, remain in a given land. This has occurred with impunity in the Falklands, North Cyprus and Nagorno-Karabakh, and Russia was well-aware of this fact. Therefore, Russia also utilized the same tactic in Abkhazia, South Ossetia, and Crimea ${ }^{293}$. China, in the meantime, has utilized a more novel and comparatively less controversial tactic for the same purposes. They created new territories from scratch (by building artificial islands) in the South China Sea and they 'replaced' the populations in the disputed maritime territories. Therefore, while they were not granted a de juro rule in this maritime zone, they were able to take de facto control - much like with Russia. Indeed, these actions constitute extra-legal conduct, especially as civilians hold rights to their property and therefore a right to be present in their now-occupied countries. Nevertheless, as they also have a right to refuse to pledge allegiance to the occupying powers, the occupying powers have an incentive to capitalize on the lack of scrutiny from and protection of such citizens' rights by the international community to change the de facto situation in their favor. Clearly, there is a link between freezing and forgetting and population displacement/replacement.

\section{A Model for Understanding Russian Behavior:}

In the previous sections, I have underlined the fact that rather than guessing at underlying motivations of the elites, it is more appropriate to simulate the cost-benefit analysis of an actor in determining their choice of tactics. In the case of Russian behavior in the Caucasus and Eastern Europe, we should therefore conduct a potential cost-benefit analysis for choosing an aggressively assertive approach. This analysis should be based on precedent and the perceived capabilities of Russia. One such simulation is provided below:

\footnotetext{
292 Caspersen, pp. 86-87.

293 Crimea is included in this context due to the initial tactics utilized in its partition from Ukraine, regardless of its annexation into Russia which differentiates it from the other cases.
} 
Figure 1: Model simulation (Source: Author.)

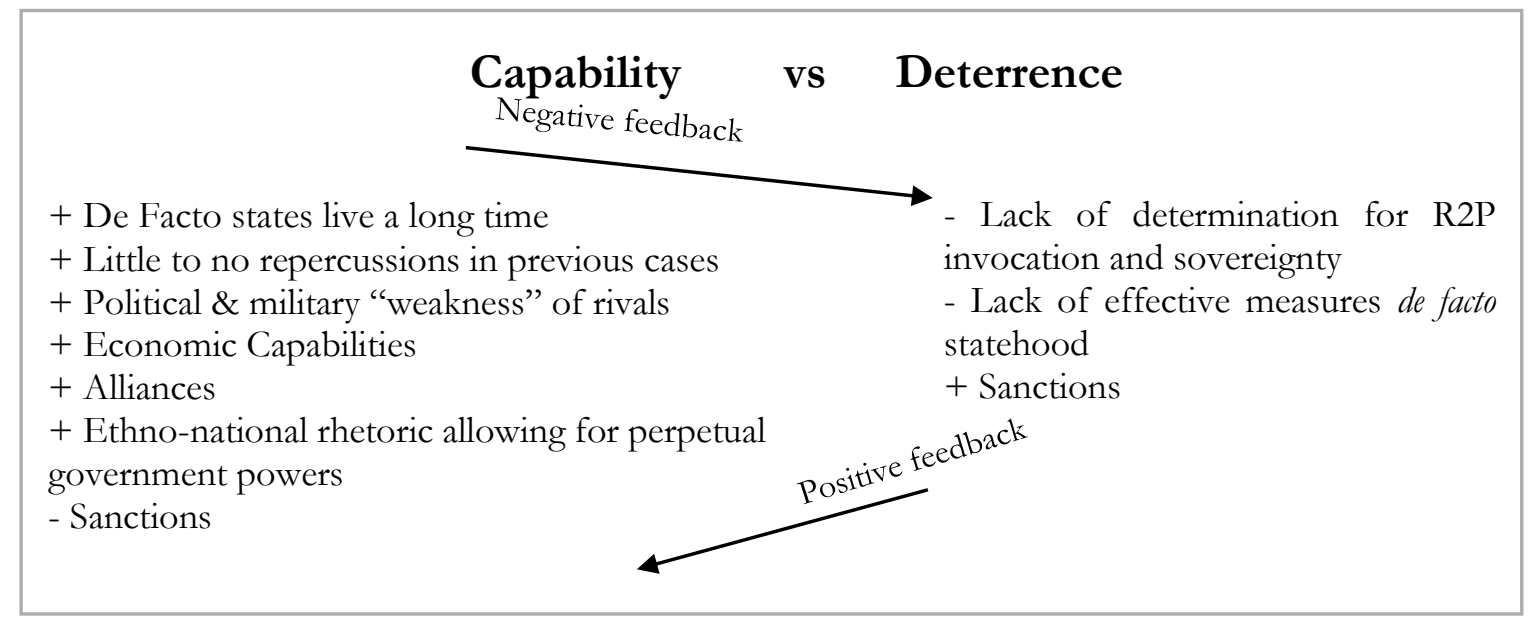

In the above model for determining Russian preferences for utilizing an aggressive tactic, the + on each side 'adds up' to its own side and the - factors subtract from the side they are on or otherwise 'add up' to the opposing side. Clearly, the model demonstrates that Russia almost cannot help but utilize territorial aggression in order to resolve territorial disputes. Given this model, we can easily claim that any nation which is militarily strong, has established powerful alliances, and possesses a strong economy will be tempted to utilize this tactic unless more effective deterrents are erected. Therefore, China can more than easily follow in Russia's footsteps - which is disconcerting from an international security viewpoint.

\section{Conclusions and Policy Suggestions:}

In this paper, I have sought to diverge from the mainstream literature by not focusing on deciphering the unknowable motivations lying behind the assertive aggression displayed by Russia and China of late. Instead, I have chosen to focus on the enablers of and deterrents against the said acts. Through this study, I have demonstrated that there are many shortcomings in the international community's approach to cases of forceful land acquisition and the establishment of de facto sovereignty. In fact, my study identified and argued for there being two main problems in need of resolution vis-à-vis Russia and China (as well as for the rest who might take these two parties' actions to constitute precedent): a) a lack of clarity regarding who is qualified to hold sovereignty and under what conditions sovereignty can be considered forfeit; and b) a lack of constructively effective strategies of intervention in cases of forceful land acquisition. Dealing with both of these deficiencies in the international system, which facilitate and even promote land grabs through conquest, must be dealt with in order to prevent future occurrences of warfare for the purposes of establishing a favorable, de facto situation vis-à-vis their territorial interests.

For the purposes of dealing with the ambiguities regarding sovereignty, it appears that a UN Convention, at the least, is a necessity. In addition, this conversation must necessarily involve some non-state entities such as De Facto States which have a stake in this decision on how to award or take away sovereignty from entities. This is especially true as many existing legitimate states would not qualify as sovereigns under the current conceptualizations, and likewise many non-state entities would qualify as such. Moreover, which specific procedures can help an entity 'earn' or validate its 
sovereignty and under which specific conditions the international community can intervene into the domestic affairs of existing, de juro States must necessarily be ascertained. Subsequently, actors seeking to pursue their interests will be unable to justify their actions through subjective interpretations of ambiguously-defined conditions, such as 'threats to minorities' human rights'.

Lastly, the freezing and forgetting policy must be re-examined and possibly replaced in its entirety. The isolationist tendencies of this policy, which distance de facto governed territories from the international community and pushes them straight into a relationship of dependence with their sponsor states, must clearly be re-examined. This holds especially true as the policy allows for ethnic cleansing and other forced changes of demographics, which have negative future implications with regards to territorial independence, democracy, and property rights. What is at stake here is the wider use of this tactic with impunity, which is especially disconcerting as the conflicts in South China Sea are heating up and might lead to open warfare, which would be sure to change the borders in this region. Moreover, any state with enough power to weather sanctions is encouraged - under the current international system - to pursue its territorial interests through force and against weaker targets. In addition, the use of sanctions does not appear to work against actors that are already powerful vis-a-vis their economics, so this also appears to be an exercise in futility. An approach where these conflicts are not pursued militarily but legally and economically where the de facto territories are given more options and therefore partitioning other countries becomes less viable an option for the perpetrators of such aggression might be considered. All in all, I believe that the international community can and should take measures to deal with the security threat as posed by the use of de facto states and forced demographic changes. 


\section{References}

\section{Negotiations}

Amir, Y. (1994). The Contact Hypothesis in Intergroup Relations. In W. J. Lonner \& R. S. Malpass, Psychology and Culture. Pearson.

Constructive Conflicts: From Escalation to Resolution. (2011) (Fourth Edition edition). Lanham, Md: Rowman \& Littlefield Publishers.

Essentials of Negotiation. (2003) (3rd International student edition edition). Boston: McGraw Hill Higher Education.

Kriesberg, P. L. (1992). International Conflict Resolution: The U.S.-USSR and Middle East Cases (1St Edition edition). New Haven: Yale University Press.

Laue, J. H. (2014). Getting to the Table: Creating the Forum for Negotiations in Deep-Rooted Conflicts. Sociological Practice, 10(1), 13.

Pruitt, D. G. (2009). Escalation and de-escalation in asymmetric conflict t. Dynamics of Asymmetric Conflict, 2(1), 23-31. http://doi.org/10.1080/17467580903214501

\section{Russia and China}

Armed Clash in the South China Sea. (n.d.). Retrieved August 29, 2015, from http://www.cfr.org/world/armed-clash-south-china-sea/p27883

China and the New International Order. (2008) (1 edition). London; New York: Routledge.

China in the International Economic Order: New Directions and Changing Paradigms. (2015). New York: Cambridge University Press.

China may fear reputation damage more than military threats over South China Sea. (2015, August 28). The Guardian. Retrieved from http://www.theguardian.com/commentisfree/2015/aug/29/china-may-fearreputation-damage-more-than-military-threats-over-south-china-sea

Cimbala, S. J. (2014). The Asian Attraction: Pivotal Priorities and Nuclear Dangers in U.S. Security Policy. Comparative Strategy, 33(2), 177-188. http://doi.org/10.1080/01495933.2014.897140

Crisis in the Caucasus: Russia, Georgia and the West. (2009). London; New York: Routledge.

Dr. Walid Abdulrahim. (n.d.). State Territory and Territorial Sovereignty. Retrieved August 31, 2015, from https://sites.google.com/site/walidabdulrahim/home/my-studies-in-english/6-state-territory-and-

territorial-sovereignty\#_ftn32

Gozman, L. (n.d.). Why Russians Liked Americans Better During the Cold War. Retrieved August 29, 2015, from http://www.politico.com/magazine/story/2015/04/russians-cold-war-116736

International Committee of the Red Cross. (2002). Belligerent Occupation. Geneva, Switzerland.

Laqueur, W. (2015). Putinism: Russia and Its Future with the West (First Edition edition). New York: Thomas Dunne Books.

Light, M. (2010). The Russo-Georgian War of 2008: A Conflict Announced in Advance? Europe-Asia Studies, 62(9), 1579-1582. http://doi.org/10.1080/09668136.2010.515799

McDougal, M. S. (1984). Law and Minimum World Public Order: Armed Conflict in Larger Context. UCLA Pac. Basin LJ, 3, 21. 
McDougal, M. S., \& Feliciano, F. P. (1958). International Coercion and World Public Order: The General Principles of the Law of War. Yale Law Journal, 771-845.

Morris, J. (2013). Libya and Syria: R2P and the spectre of the swinging pendulum. International Affairs, 89(5), $1265-1283$.

Qc, M. N. S. M. N. S. (2012). The International Law of Territory. Oxford: Oxford Univ Pr.

Russian Foreign Policy: Interests, Vectors, and Sectors. (2013). Los Angeles: Cq Pr.

Sarotte, M. E. (2009). 1989: the struggle to create post-Cold War Europe. Princeton, N.J: Princeton University Press.

Schneider, M. (2014). Minimum Deterrence and Russian and Chinese Threat Developments. Comparative Strategy, 33(3), 193-204. http://doi.org/10.1080/01495933.2014.926715

Sussex, M. (Ed.). (2012). Conflict in the Former USSR (1 edition). Cambridge England ; New York: Cambridge University Press.

Turner, S. (2011). China and Russia After the Russian-Georgian War. Comparative Strategy, 30(1), 50-59. http://doi.org/10.1080/01495933.2011.545687

\section{Timor Leste}

Bacharuddin, W. A. M. (2014). The Right for Self-Determination of East Timorese from Liberalist Perspective (thesis), Indonesia Universitas Jogyakarta.

Cotton, J (2007). Against the Grain: The East Timor Intervention. Survival: Global Politics and Strategy (n.), $127-142$.

Martin, I. (2011). Self-Determination in East Timor. Boulder, CO: Lynne Rienner.

\section{Other}

Bakke, K. M., "After the war ends: violence and viability of post-Soviet unrecognized states” in Unrecognized States in the International System, edited by N. Caspersen and G. Stansfield, 2011, NY: Routledge Press, pp. 89-109.

Caspersen, N., 2011. "States without sovereignty: imitating democratic statehood" in Unrecognized States in the International System, edited by N. Caspersen and G. Stansfield, NY: Routledge Press, pp. 73-89.

, and G. Stansfield, 2011. "Introduction: unrecognized states in the international system" in Unrecognized States in the International System, edited by N. Caspersen and G. Stansfield, NY: Routledge Press, pp. 1-8.

, and (eds.), 2011. Unrecognized States in the International System. NY: Routledge Press.

Chorev, M, 2011. "Complex trrains: unrecognized states and globalization" in Unrecognized States in the International System, edited by N. Caspersen and G. Stansfield. NY: Routledge Press, pp. 27-40.

Closson, S, 2011. "What do unrecognized states tell us about sovereignty?" in Unrecognized States in the International System, edited by N. Caspersen and G. Stansfield. NY: Routledge Press, pp. 58-69.

Coleman, P. T. (2011). The Five Percent: Finding solutions to seemingly impossible conflicts. NY: Public Affairs Publishers.

Grant, T. D., 1999. The Recognition of States: Law and Practice in Debate and Evolution, Westport: Praeger. 
Harvey, J. and G. Stansfield, 2011. "Theorizing unrecognized states: sovereignty, secessionism, and political economy" in Unrecognized States in the International System, edited by N. Caspersen and G. Stansfield, NY: Routledge Press, pp. 11-26.

King, C., 2001. The Benefits of Ethnic War: Understanding Eurasia's Unrecognized States. World Politics 53: July 2001, pp. 524-552.

Kolsto, P. and H. Blakkisrud, 2011. "'Separatism is the mother of terrorism': internationalizing the security discourse on unrecognized states" in Unrecognized States in the International System, edited by N. Caspersen and G. Stansfield. NY: Routledge Press, pp. 110-127.

Pegg, S., 1999. International Society and the De Facto State. UK: Ashgate Pub Ltd.

Rutland, P., 2007. Frozen Conflicts, Frozen Analysis. [online], available at: http://prutland.web.wesleyan.edu/Documents/Frozen conflicts.pdf

Wolff, S., 2011. "The limits of international conflict management in the case of Abkhazia and South Ossetia" in Unrecognized States in the International System, edited by N. Caspersen and G. Stansfield. NY: Routledge Press, pp. 147-164. 